\title{
Permo-Triassic metamorphism in the Mérida Andes, Venezuela: New insights from geochronology, $\mathrm{O}$ - isotopes, and geothermobarometry
}

M. DANIELA TAZZO-RANGEL ${ }^{1 *}$, BODO WEBER ${ }^{1}$, AXEL K. SCHMITT $^{2}$, RENEÉ GONZÁLEZ-GUZMÁN ${ }^{1}$, LUTZ HECHT ${ }^{3}$

${ }^{1}$ Centro de Investigación Científica y de Educación Superior de Ensenada (CICESE). Carretera Ensenada-Tijuana, No. 3918 22860, Ensenada B.C., México.

(*mtazzo@cicese.mx, bweber@,cicese.mx, rguzman@,cicese.mx)

${ }^{2}$ Institute of Earth Sciences, Heidelberg University, Heidelberg, Germany. axel.schmitt@geow.uniheidelberg.de

${ }^{3}$ Museum für Naturkunde, Leibniz-Institut für Evolutionsund Biodiversitätsforschung, Berlin, Germany. lutz.hecht@mfn.berlin

Although there is a consensus about Pangea assemblage spanning from the Late Carboniferous to the Early Permian in northwestern Gondwana, the tectonics of the Late PermianEarly Triassic period, including the onset of Pangea breakup, is still controversial. In this context, two regional tectonic features need to be considered: the Ouachita-MarathonSonora suture to the north, and the east-dipping subduction of the Panthalassa oceanic crust beneath Gondwana to the west. A chemical, isotopic, and geochronological dataset is presented in this contribution to constrain the effects of these tectonic processes in the metamorphic basement of the Mérida Andes in western Venezuela. U-Pb secondary ion mass spectrometry analyses on unpolished surfaces of zircon grains from gneissic rocks yielded an average age of $251.1 \pm 4.0$ Ma. The corresponding $\delta^{18} \mathrm{O}$ values suggest metamorphic recrystallization in zircon instead of high- $\mathrm{T}$ fluid interaction. Furthermore, $\mathrm{Rb}-\mathrm{Sr}$ and $\mathrm{Sm}-\mathrm{Nd}$ thermochronology in white mica and garnet yielded ages of 243.6 $\pm 9.3 \mathrm{Ma}$ and $249.3 \pm 1.8 \mathrm{Ma}$, respectively. Thus, the combination of three geochronometers involving different mineral phases allows constraining, for the first time, the Latest Permian-Earliest Triassic metamorphism in the Mérida Andes at 250 $\pm 3.0 \mathrm{Ma}$. Amphibolite-facies peak metamorphic conditions at $\sim 680{ }^{\circ} \mathrm{C}$ and $\sim 8.0 \mathrm{kbar}$ are estimated via pseudosection modeling and geothermobarometry in distinct mineral assemblages of pelitic paragneiss and hornblende orthogneiss. Metamorphism was possibly triggered by postorogenic gravitational collapse after the collision of Gondwana and Laurentia to form Pangea. Retrogression between $\sim 240 \mathrm{Ma}$ and $\sim 200 \mathrm{Ma}$ was probably driven by thermal relaxation of tectonically overthickened crust. 